\title{
Longevity in the Light of the Latest Data
}

\author{
VÄINÖ KANNISTO, Ph.D. \\ Demographic Statistics Consultant
}

The postwar development of old age life expectancy (Figure 1) is one of generalized increase but with varying speed and many crossovers between countries. Women live clearly longer than men and the difference has been growing. In a general way, the increase in life expectancy was slower in the early decades and has later accelerated. In the group of large countries (top charts), Japan and France are in the lead. Starting at a lower level, Japan has experienced spectacular improvement since about 1960, while the progress has beed steadier in France. The life expectancy of Dutch men, traditionally high, has been stagnating while that of women has shown moderate growth.

Among the smaller countries (bottom charts), Switzerland has seen steady and rapid increase, which has carried it well past the Scandinavian countries. In Norway, another country of traditionally low mortality in old age, men have experienced almost no increase and women relatively little. Finland, beginning from a much lower level, has shown rapid increace since about 1970 and has come close to Denmark, which has now the lowest values in Scandinavia proper. The changes are summarized in Table 1, pp. 28.

The decline of old age mortality has been highly age-selective. Merging the data for thirteen countries (the ten shown in Figure 1 plus Italy, Austria and Iceland), and dividing the 40 years which separate 1950-55 from 1990-95 into two periods of equal length, we note in Figure 2 that during the first period the mortality of women of 80 declined by 1.5 percent a year but that of 100 -year-olds by only 0.5 percent.

In the second period the decline at 80 had accelerated to 2.5 percent a year, while that of the centenarians was only slightly greater than before.

For men, mortality decline was quite slow in the earlier period with hardly any sign of ageselectivity. This, however, was an average for countries with different histories. In some (Japan, France, Switzerland), the decline was altogether faster and particularly so at ages near 80 , while in some others (e.g. Denmark) mortality of middle-aged men actually increased sending ripple effects beoynd afe 80 . In the second period the mortality decline for men accelerated and took on the same age profile as that of women. It may be concluded from this 
that when the factors behind the recent decline in old age mortality operate without interference by causes of death more specific to middle age, the result is an age profile of gradually declining progress as age advances.

Figure 1. Development of life expectancy at age 80
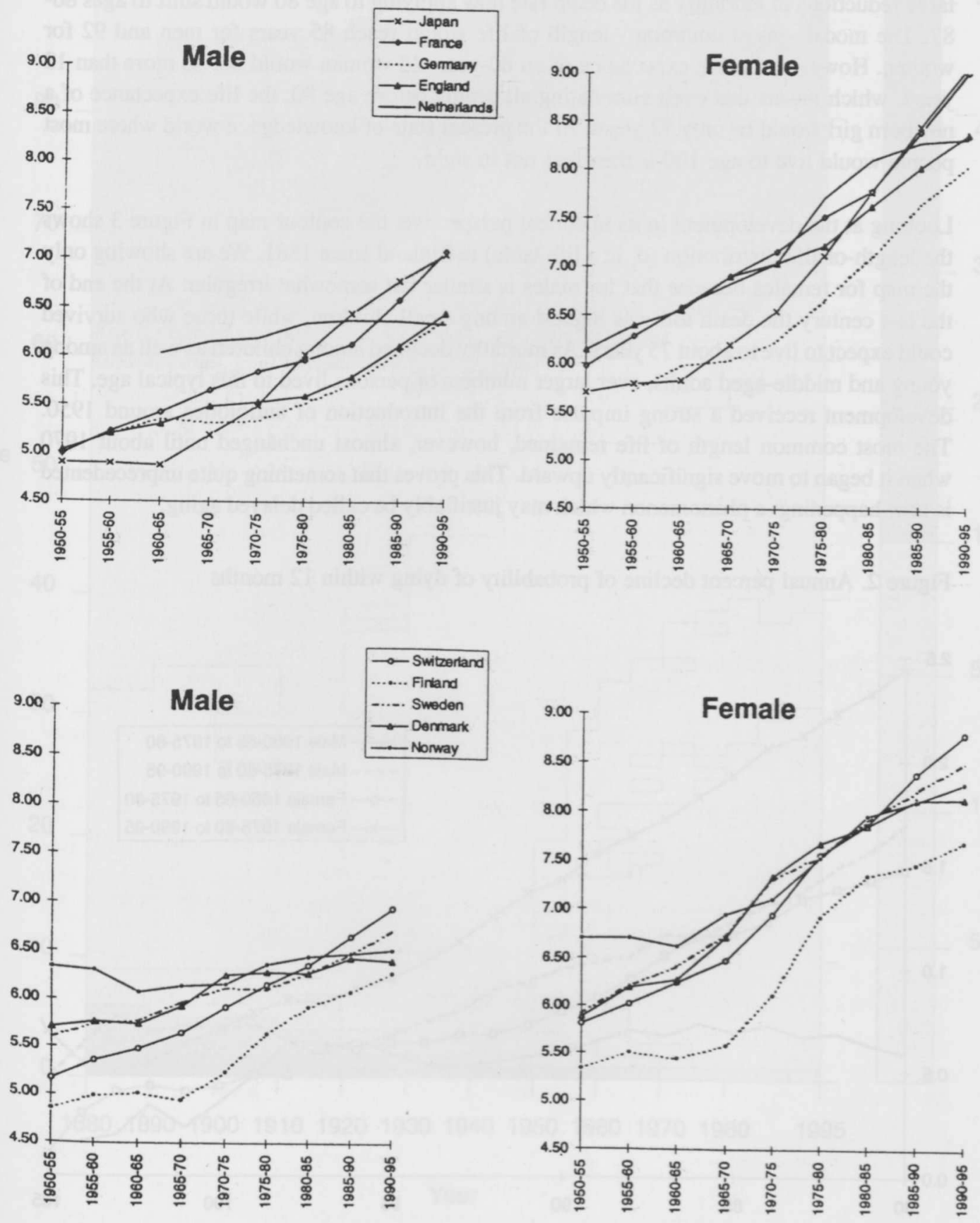
Though mortality has declined less among the very oldest, the lives saved cumulate from age to age and therefore, the higher the age, the faster the relative increase in numbers has been. According to Table 2 the number of octogenarians has grown by 3 to 5 times but that of centenarians by more than 20 times. Yet the very old remain a small fraction of the total population, 3 percent, and there is only one centenarian per 20,000 people.

Extrapolation of the present rate of mortality decline up to the year 2050 (Table 3) indicates large reductions in mortality as the death rate now applying to age 80 would shift to ages 86 87. The modal - most common - length of life would reach 85 years for men and 92 for women. However, the life expectancy of an 80-year-old woman would not be more than 12 years, which means that even eliminating all deaths before age 80 , the life expectance of a newborn girl would be only 92 years. At the present state of knowledge, a world where most people would live to age 100 is therefore not in sight.

Looking at the development in its historical perspective, the contour map in Figure 3 shows the length-of-life distribution ( $d_{x}$ in a life table) in Finland since 1881 . We are showing only the map for females because that for males is similar but somewhat irregular. At the end of the last century the death toll was highest among small children, while those who survived could expect to live to about 75 years. As mortality declined among children as well as among young and middle-aged adults, ever larger numbers of persons lived to this typical age. This development received a strong impulse from the introduction of antibiotics around 1950 . The most common length of life remained, however, almost unchanged until about 1970 when it began to move significantly upward. This proves that something quite unprecedented is now happening: a phenomenon which may justifiably be called delayed aging.

Figure 2. Annual percent decline of probability of dying within 12 months

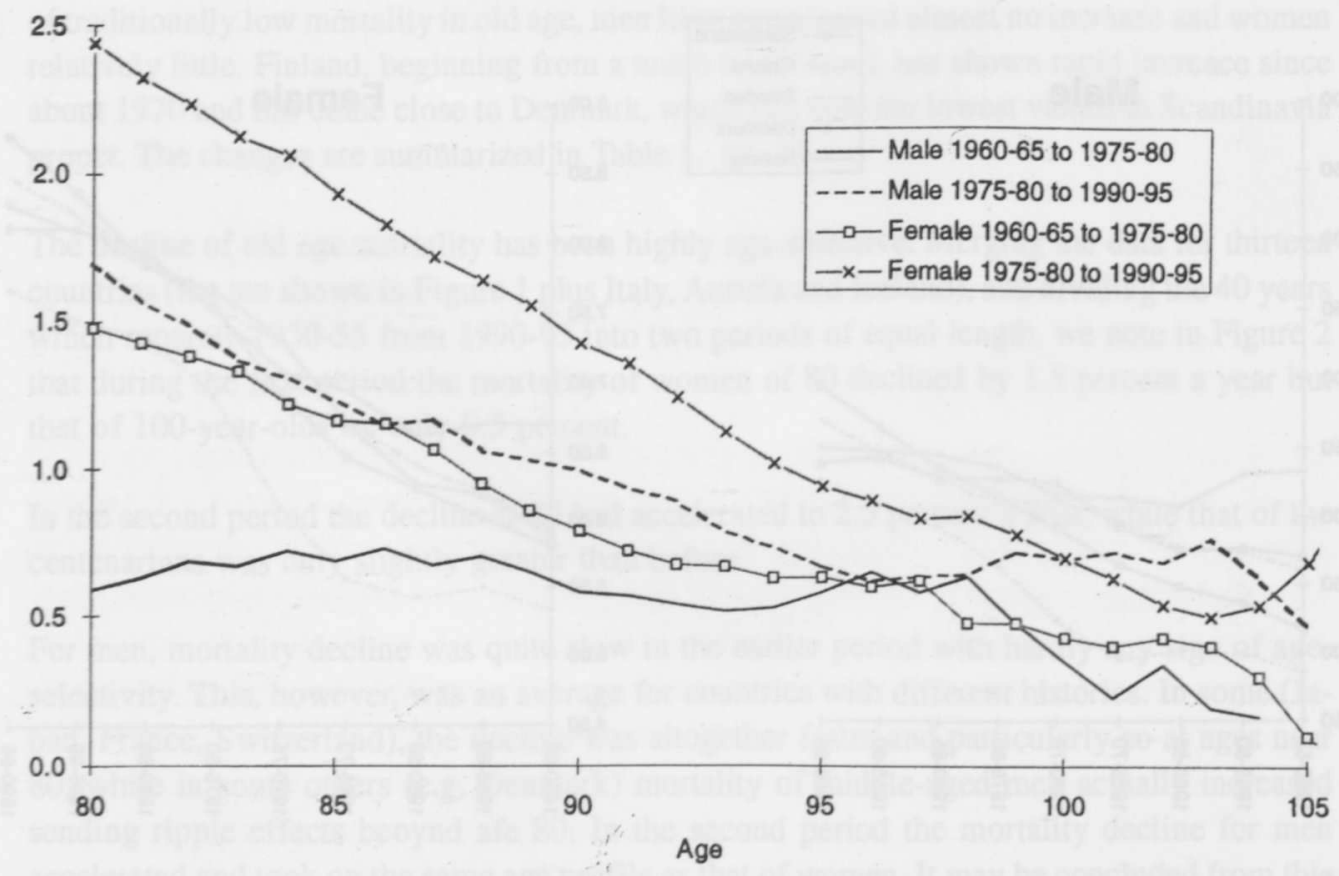


Figure 3. Deaths out of 100,000 live births, Finland, females

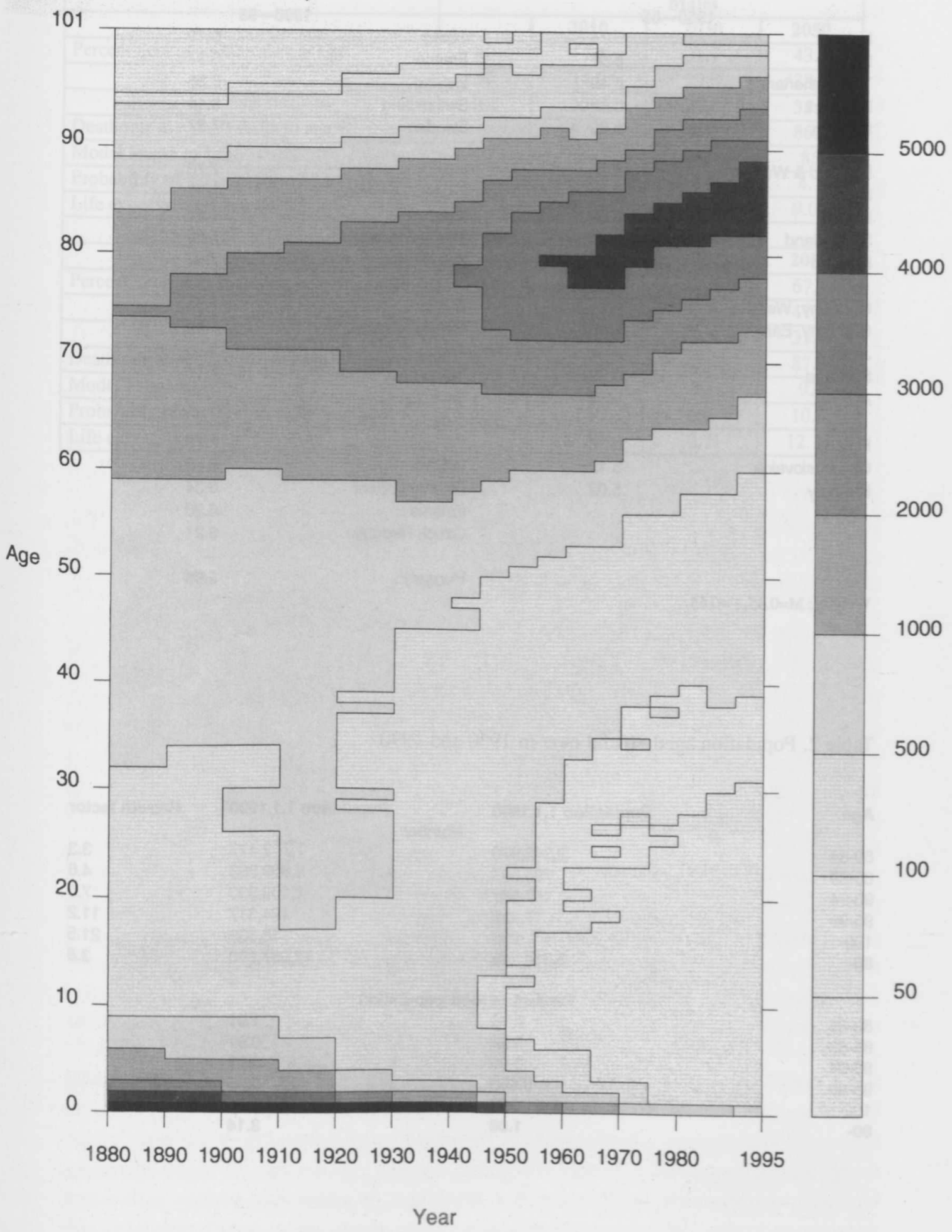


Table 1. Life expectancy at age 80 . Both sexes

$\begin{array}{llll} & \mathbf{1 9 5 0 - 5 5} & & \text { 1990-95 } \\ \text { Iceland } & 6.74 & \text { Japan } & 8.40 \\ \text { Norway } & 6.57 & \text { France } & 8.37 \\ \text { The Netherlands } & 6.40 & \text { Iceland } & 8.36 \\ \text { Denmark } & 5.82 & \text { Switzerland } & 8.14 \\ \text { Sweden } & 5.80 & \text { Sweden } & 7.87 \\ & & & \\ \text { England \& Wales } & 5.75 & \text { Italy } & 7.78 \\ \text { France } & 5.63 & \text { England \& Wales } & 7.72 \\ \text { Ireland } & 5.63 & \text { Norway } & 7.67 \\ \text { Switzerland } & 5.58 & \text { The Netherlands } & 7.65 \\ \text { Belgium } & 5.55 & \text { Denmark } & 7.52 \\ & & & \\ \text { Germany, West } & 5.54 & \text { Belgium } & 7.51 \\ \text { Germany, East } & 5.43 & \text { Germany, West } & 7.49 \\ \text { Japan } & 5.42 & \text { Austria } & 7.26 \\ \text { Scotland } & 5.39 & \text { Finland } & 7.19 \\ \text { Austria } & 5.36 & \text { Scotland } & 7.16 \\ \text { Finland } & & & \\ \text { Czechoslovakia } & 5.16 & \text { Portugal } & 6.73 \\ \text { Hungary } & 5.12 & \text { Ireland } & 6.69 \\ & 5.02 & \text { Germany, East } & 6.34 \\ & & \text { Estonia } & 6.28 \\ & & \text { Czech Republic } & 6.21 \\ \text { Weights: M=0.35, F=0.65. } & & & \\ & & \text { Hungary } & 5.96 \\ & & & \end{array}$

Table 2. Population aged 80 and over in 1950 and 1990

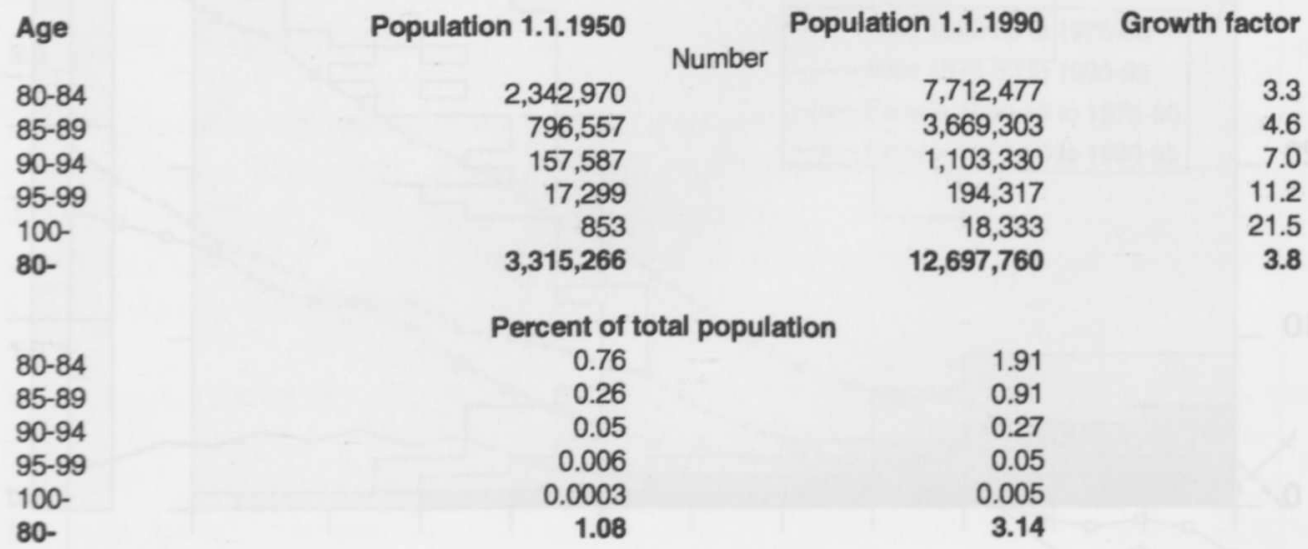


Table 3. Some indicators projected to year 2050 , thirteen countries

\begin{tabular}{|c|c|c|c|c|}
\hline & & \multicolumn{3}{|c|}{ Males } \\
\hline & & 2010 & 2030 & 2050 \\
\hline Percent decline in mortality at age & 80 & 17.4 & 31.7 & 43.5 \\
\hline & 90 & 14.9 & 27.6 & 38.4 \\
\hline & 100 & 12.0 & 22.6 & 31.9 \\
\hline \multicolumn{2}{|l|}{ Death rate at age 80 shifts to age... } & 82.1 & 84.2 & 86.2 \\
\hline \multicolumn{2}{|l|}{ Modal length of life } & 82 & 83 & 85 \\
\hline \multicolumn{2}{|l|}{ Probability of survival from 80 to $100, \%$} & 1.3 & 2.6 & 4.7 \\
\hline \multirow{3}{*}{\multicolumn{2}{|c|}{ Life expectancy at age 80}} & 7.13 & 8.06 & 9.05 \\
\hline & & \multicolumn{3}{|c|}{ Females } \\
\hline & & 2010 & 2030 & 2050 \\
\hline \multirow[t]{3}{*}{ Percent decline in mortality at age } & 80 & 31.0 & 52.3 & 67.1 \\
\hline & 90 & 19.4 & 35.0 & 47.7 \\
\hline & 100 & 12.0 & 22.6 & 31.9 \\
\hline \multicolumn{2}{|l|}{ Death rate at age 80 shifts to age... } & 82.7 & 85.1 & 87.0 \\
\hline \multicolumn{2}{|l|}{ Modal length of life } & 88 & 90 & 92 \\
\hline \multicolumn{2}{|l|}{ Probability of survival from 80 to $100, \%$} & 3.5 & 6.6 & 10.8 \\
\hline \multicolumn{2}{|l|}{ Life expectancy at age 80} & 9.25 & 10.71 & 12.14 \\
\hline
\end{tabular}

